\title{
$\angle S$ Research Square \\ Nesting Effects of Climate and Local Drivers on Long-Term Subalpine Fires in the Alps
}

Christopher Carcaillet ( $\nabla$ christopher.carcaillet@ephe.psl.eu )

Paris Sciences \& Lettres University (PSL) https://orcid.org/0000-0002-6632-1507

Benjamin Boulley

Paris Sciences \& Lettres University (PSL)

Frédérique Carcaillet

Université de Montpellier

Research

Keywords: Fire, Biomass burning, Subalpine forest, Climate, Landscape features, Pedoanthracology, Radiocarbon dating

Posted Date: October 11th, 2021

DOI: https://doi.org/10.21203/rs.3.rs-955274/v1

License: (c) (i) This work is licensed under a Creative Commons Attribution 4.0 International License. Read Full License 


\section{Abstract}

Background: The present article questions the relative importance of local- and large-scale processes on the long-term dynamics of fire in the subalpine belt in the western Alps. The study is based on soil charcoal dating and identification, several study sites in contrasting environmental conditions, and sampling of soil charcoal along the elevation gradient of each site. Based on local differences in biomass combustion, we hypothesize that local-scale processes have driven the fire history, while combustion homogeneity supports the hypothesis of the importance of large-scale processes, especially the climate.

Results: The results show that biomass burning during the Holocene resulted from the nesting effects of climate, land use, and altitude, but was little influenced by topography (slope exposure: north versus south), soil (dryness, pH, depth), and vegetation. The mid-Holocene (6500-2700 cal BP) was an important period for climatic biomass burning in the subalpine ecosystems of the western Alps, while fires from about 2500 years ago appear much more episodic, prompting us to speculate that human society has played a vital role in their occurrence.

Conclusion: Our working hypothesis assuming that the strength of mountain natural and local drivers should offset the effects of regional climate is not validated. The homogeneity of the fire regime between sites thus underscore that climate was the main driver during the Holocene of the western Alps. Longterm subalpine fires are controlled by climate at millennial scale. Local conditions count for little in determining variability at the century scale. The mid-Holocene was a chief period for climatic biomass burning in the subalpine zone, while fires during the late Holocene appear much more episodic, prompting the assumption that societal drivers has exercised key roles on their control.

\section{Introduction}

Events in recent years have dramatically shown that wildfires are essentially under the control of extreme heatwaves. The overall regulation of wildfires by climate is undoubted (e.g., Bond and Keeley 2005; Flannigan et al. 2009; Moritz et al. 2012) and this should be on the agenda of states and UNO stakeholders (IPCC 2021). However, other drivers also act on wildfire regimes: soil granulometry, slope exposure, biomass quality and load, topography, altitude, landscape pattern, and, of course, past or present land uses all play their part (Loehman et al. 2013). The relative function of climatic and nonclimatic drivers can be tricky to unravel, while the local management of a fire regime needs such fine distinctions in order to implement efficient management processes according to actual risks. Cold regions like boreal or temperate mountains present biomass with very similar elements in terms of climate (temperature, precipitation, seasonality, snow cover, etc.) and biota (functionally analogue woody species, structure of vegetation, etc.). However, they differ by their relief, which determines the fragmentation and the heterogeneity of landscape (slope degree and exposure, altitude, etc.). The altitude controls the moisture and the temperature (wetter and colder with increasing elevation) and the partial pressure of $\mathrm{O}_{2}$ $\left(\mathrm{pO}_{2}\right)$ that is the biomass oxidizer during fire ( $10 \%$ change of $\mathrm{pO}_{2}$ per $1000 \mathrm{~m}$ in elevation). Further, the slope controls the water run-off and drainage, and the exposure regulates the solar radiation and the 
length of the growing season (Tian et al. 2001; Piedallu and Gégout 2007) with potentially significant effects on the fire regime (Schumacher and Bugmann 2006). To sum up, as a first approximation, a number of evident similitudes warrant some comparisons or assumptions between boreal and mountain systems, but the differences strongly encourage caution when considering management planning for wildfire and forest resources (Loehman et al. 2014; Moritz et al. 2014).

Here we test whether the past climate controlled the fire regime in a temperate mountain region over the last 11 millennia, i.e. during the Holocene - a warmer and more humid time in mountains compared to Glacial and Lateglacial periods that were colder and drier. The principles of the study are based on the hierarchy theory (O'Neill 1988; Allen 2009), which states that if climate is the main driver, different sites that are close to each other should reveal similar pattern of fire regime (Yocom Kent et al. 2017). If they do not show such similarities, local drivers must be considered, notably slope exposure, altitude, soil type, and vegetation. Of course, historic land use must also be taken into account as an important fire driver (Zumbrunen et al. 2009), but this has been difficult to prove in the past without resorting to speculation because accurate quantitative evidences of past land uses are often lacking, e.g., chronics of people density, their savoir faire, and technologies. Vegetation is under the direct influence of mountain climate and soil types, through bedrocks that notably control the plant communities and their productivity. The vegetation is also largely shaped and controlled by traditional land uses that generally exclude woody plants and seek to sustain mountain grasslands that are not fire-prone. When traditional land use in this context is abandoned, subalpine woody plants recover in decades (e.g., Tasser and Tappeiner 2002; Motta and Lingua 2005; Tasser et al. 2007; Lingua et al. 2008). For our purposes then, we here study three sites in close proximity, all located in the same valley of the western Alps. In each site, charcoals were extracted from several natural subalpine soils along the altitudinal gradient and further radiocarbon dated. The numerical analysis of ${ }^{14} \mathrm{C}$ datings allows reconstructing of biomass burning as a surrogate of fire history (Payette and Gagnon 1985; Carcaillet 1998; Gavin et al. 2003), and enables us to determine homogeneities and differences by considering local drivers. Charcoal fragments were identified to reconstruct the past burned biomass, helping to test whether different woody communities were historically involved in these past fires. Here, two sites - both situated on south-facing slopes but contrasted by their soil - were selected: acidic and well supplied with water versus alkaline with poor water storage. The third site is in between in terms of soil, but has north-facing slopes. This last condition (a north-facing site) should result in less biomass burning (more stochastic), while a south-facing site on poor water storage soil should in theory promote a more homogeneous chronology of biomass burning starting earlier during the Holocene, especially if vegetation was more fire-prone.

We hypothesize that due to the strength of mountain contrasts natural local drivers should offset the effects of regional climate. Alternatively, the homogeneity of the fire regime between sites would suggest that climate was the main historical driver. Confirmation of either hypotheses should result in different scenarios of land management, notably in planning the future of forest and woodlands facing the global warming that will almost certainly be accompanied by more frequent and severe drought in the Alps (Gao and Giorgi 2008; Im et al. 2010) - a sine qua none condition for dealing with future fire occurrences 
(Zumbrunen et al. 2009; Dupiré et al. 2019). The study is articulated on reused AMS ${ }^{14} \mathrm{C}$ dating already published (i.e., 34 by Carcaillet 1998, 10 by Carcaillet 2001) and on 49 unpublished datings, including 24 on a contrasted site. Finally, while this approach based on soil charcoal is opportune for exploring the fire history of dry sites, it is unsuitable for classic sedimentary studies. A planning bias in land management, based on paleo-data from areas characterized by lakes and peatlands, would be to extrapolate these findings to unsuitable sites due to edaphic or climatic dryness that might therefore be subject to important fire regimes for millennia.

\section{Material And Methods}

\section{Study sites}

The three study sites are situated in the Maurienne valley that borders the Vanoise massif to the south, in western France. The three sites, namely St Michel, Aussois, and Lanslevillard, are situated at the same latitude (ca $45.25^{\circ} \mathrm{N}$ ) along a west-east transect of ca $40 \mathrm{~km}$ corresponding to a gradient of humidity linked to a complex rain-shadow process. St Michel is the most western site, $21 \mathrm{~km}$ from Aussois, the central site, and Lanslevillard is the easternmost of the three $-17 \mathrm{~km}$ from Aussois (geographic coordinates: Table 1).

St Michel is characterized by south-facing slopes and acidic soils on bedrock composed of glacial thin deposits of admixed coalesced sandstones and shale rock fragments (Table 1). Aussois is also on southfacing slopes but has alkaline bedrocks mostly composed of thick glacial deposits $(>150 \mathrm{~cm})$ : an admixture of dolomitic-origin, cargneule, and gypsum. Lanslevillard is on north-facing slopes but with alkaline bedrock resulting from a glacial admixture of marbles and calcareous shale fragments (Geologic maps 775 and 776). At St Michel and Lanslevillard, forest soils are acidic or neutral brunisol, respectively, whereas at Aussois soils are calcimorph with pH >7 (Bartoli 1967; Mourier et al. 2008). Slope degrees range between 20 and $30^{\circ}$ (Table 1), but if St Michel and Lanslevillard show regular slopes, Aussois presents more heterogeneous terrain.

Climate features vary between sites according to slope exposure and altitude of weather stations: ca $1400 \mathrm{~m}$ above sea level (hereafter asl) at St Michel and Aussois, and $2000 \mathrm{~m}$ asl at Lanslevillard, resulting in temperature values that are not totally comparable (Table 1). However, mean annual temperatures appear similar (ca $7^{\circ} \mathrm{C}$ at $1400 \mathrm{~m}$ on south-facing slopes and ca $2.5^{\circ} \mathrm{C}$ at $2000 \mathrm{~m}$ on northfacing). The mean monthly temperatures for the three winter months $\left(T_{D J F}\right)$ are around $0^{\circ} \mathrm{C}$ at $1400 \mathrm{~m}$ and $-4^{\circ} \mathrm{C}$ at $2000 \mathrm{~m}$, and the three of the growing season $\left(T_{J J A}\right)$ are ca $14.5^{\circ} \mathrm{C}$ at $1400 \mathrm{~m}$ and $10^{\circ} \mathrm{C}$ at $2000 \mathrm{~m}$. Snow covers the ground for 3-5 months per year at $2000 \mathrm{~m}$ on southern slopes and $5-7$ months on north-facing slopes (Table 1). Mean annual precipitation ranges between ca $900-950 \mathrm{~mm}$ at St Michel and Lanslevillard, and ca 700 at Aussois. Aussois is clearly the driest site, with only ca $160 \mathrm{~mm}$ cumulated during the growing season, while both other sites receive $200-250 \mathrm{~mm}$, i.e. $+40 \%$ (Table 1 ). 
To sum up, Aussois is the most stressed site for biological processes in terms of climate and soil, lowest precipitation, south-facing slopes (high solar radiation on soil increasing the effect of air temperature), alkaline and calcimorph deep morainic soil depleted in clay (and thus poor water storage). Lanslevillard is the coldest site with a shorter growing season, and St Michel is the site with the most acidic soil features.

\section{Soil sampling and charcoal extraction}

At St Michel, ten soil profiles were collected, eight at Aussois, and six at Lanslevillard. All sampling plots were selected in the subalpine belt (1700-2500 m asl) in Aussois and St Michel, whereas at Lanslevillard the sampling plots were selected between 1600 and $2300 \mathrm{~m}$ asl to take into account the slope exposure that triggers a lowering of about $200 \mathrm{~m}$ of vegetation belt limits between south- and northfacing slopes (less solar radiation, shorter growing season, colder air and soil temperatures, longer snow cover in spring). The mean ( \pm SE) sampling altitudes are $2109 \pm 87 \mathrm{~m}$ at St Michel, $2051 \pm 80 \mathrm{~m}$ at Aussois, and $1970 \pm 79$ at Lanslevillard.

Soils were collected according to the standardized pedoanthracological method (Carcaillet and Thinon 1996; Carcaillet and Talon 2001). Plots disturbed by human settlements were avoided, as well as soil located at the foot of steep or long slopes susceptible to concentrated charcoal transported by run-off (Talon et al. 2005), or eroded or hydromorphic soils poorly favorable to particulate sequestration. Soil profiles were sampled in trenches dug down to the bedrock whenever possible, or to the limits of plant roots on thick morainic deposits. Soil material was sampled by cutting soil blocks from the face of a vertical profile. Blocks were collected at different depths from the bottom to the surface to avoid particles falling from the upper horizons. Block limits were separated in several layers when the horizon thicknesses were greater than $20 \mathrm{~cm}$ or when the soil horizon limits were not visible. About ten to 15 liters of dry fine material were sampled per layers of ca $20 \mathrm{~cm}$. Each complete dried profile weighed 30 to $100 \mathrm{~kg}$ depending on the soil texture, the organic content, and the horizon structures, and the depth of the profiles that determine the number of layers, from one to seven for 30 and $150 \mathrm{~cm}$ thick profiles, respectively.

A flotation procedure with an ascending water flow was used to extract charcoal from the soil matrix (Carcaillet and Thinon 1996). Flotation with wet sieving followed by manual sorting under a binocular microscope, allowed the final separation of charcoal fragments from other soil particles. Only fragments larger than $0.4 \mathrm{~mm}$ in diameter were considered. Charcoal that is smaller than $0.4 \mathrm{~mm}$ may be transported over long distances, while the stand origin of charcoal larger than $0.4 \mathrm{~mm}$ is unequivocal (Clark et al. 1998; Ohlson and Tryterud 2000; Lynch et al. 2004).

\section{Dating and biomass burning chronology}

In total, 93 AMS ${ }^{14} \mathrm{C}$ datings were obtained from soils at St Michel (43), Aussois (26), and Lanslevillard (24). Thirty-four (34) out of these 93 AMS ${ }^{14} \mathrm{C}$ datings were already published, 18 at St Michel and 16 at Aussois (Carcaillet 1998). Because in this preliminary study of 1988 (i) no dates covered the recent period 
from 2200 calendar years before the present (hereafter, cal BP) above $2000 \mathrm{~m}$ asl at Aussois and above $1700 \mathrm{~m}$ asl at St Michel, and (ii) none was obtained before 6500 cal BP (Carcaillet 1998), the strategy was to increase significantly the number of datings to fill in these gaps in the chronologies, or to strengthen the already reported pattern. The point was to question whether these chronological gaps resulted in a problem of low numbers or to see if they correspond to an actual lack of burning in some sites at certain altitudes. The additional site (Lanslevillard) allows us to test whether these reported chronologies per altitude class were strictly local/artifactual or corresponded to a general pattern. In this region of the western Alps, no accurate sedimentary charcoal series are available below $2000 \mathrm{~m}$ asl (Leys and Carcaillet 2016), which prevents us formulating a response to this issue of fire patterns according to altitude. We assume that fire occurrences should be more frequent at lower altitudes and on south-facing slopes compared to higher altitudes and north-facing slopes due to greater dryness (precipitation increases with elevation and south-facing slopes receive more solar radiation) (Schumacher and Bugmann 2006), and posit their greater attractiveness to prehistoric humans who altered fire patterns in response to the drivers prevailing thousands of years ago, e.g., climate, vegetation, topography, soil, etc. (Leys and Carcaillet 2016; Vannière et al. 2016).

With a few exceptions (Table S1), each dating was measured on one charcoal fragment. Prior to AMS dating, charcoal fragments were cleaned using an ultrasonic wave generator under a microscope $(\times 40)$ to remove small roots, fungi hyphae, and particles that could potentially alter the dating result. Further, each fragment was processed with a solution of $\mathrm{Na}_{4} \mathrm{P}_{2} \mathrm{O}_{7}$ or $\mathrm{NaP}_{2} \mathrm{O}_{4}$ to extract the organic compounds adsorbed in the charcoal porosity. The solution was changed daily up to the release end of organic compounds by the charcoal. Generally, five to seven days were needed to chemically clean the charcoal fragments (Carcaillet and Thinon 1996).

The ${ }^{14} \mathrm{C}$ measurements were processed by several laboratories: the NSF Arizona Facility Laboratory (Arizona, USA), the Centre de Datation par le Radiocarbone (France), and the LMC14 (a national facility lab, also in France). Dating codes were respectively labeled AA-xxxx, Lyon(OxA)-xxxx, and SacA-xxxx (Table S1).

The radiocarbon measurements were calibrated against dendrochronological years using the $C A L I B$ program version 8.2, based on the IntCal20 dataset (Stuiver et al. 2021), and reported as intercept with 2 sigma and a probability range of 1.0 . The probability distributions of ${ }^{14} \mathrm{C}$ datings were cumulated by site (e.g., Hajdas et al. 2007) and labeled local chronology. The probability distributions were obtained using the sum probability function of the CALIB program. Contrary to some assumptions (e.g., Payette et al. 2012; Couillard et al. 2021), such distribution cannot provide a chronology of fire events, but rather a chronology of biomass burned. Important lags between the ${ }^{14} \mathrm{C}$ date (radiocarbon age of wood) and the age of fire can exist, notably if the charcoal fragments used for dating came from the inner part of trunks for long-lived species such as those growing in subalpine forests (Carcaillet 1998). To bypass this problem - which Gavin (2001) called the 'inbuilt age' - and in the absence of a fuel load/consumption model to fix it (Gavin 2001), charcoal fragments corresponding to twigs were here selected for dating, when possible to reduce the range of the so-called inbuilt age. However, a maximum of cumulated 
calibration does not correspond to a fire event but to a stochastic period of burned biomass characterized by a concentration of ${ }^{14} \mathrm{C}$ dating and associated probability of calibration.

The statistical analyses of radiocarbon dating were based on their distribution revealed through violinplots ( $R$ package, ggplot2). The violin-plot is more informative than the box-plots sometimes used to establish dating distribution (e.g., Gavin et al. 2003), because a multimodal distribution is visual and illustrated by two bulges at least, whereas a unimodal distribution should present only one. The site distributions were statistically compared to each other based on ANOVA followed by Tukey HSD post-hoc test to determine whether differences occur between pairs of sites. Calendar dates cannot be directly used because a date corresponds to a complex range of values, sometimes to several ranges associated with different probabilities within the full calibration range of the date considered. Consequently, the mode of each calendar date was extracted from CALIB and used as representative of the dating for violinplots and ANOVA. The mode value divides the graph of the density function into two parts with equal probability, i.e. $p=0.5$ (Michczyński 2007). This process is not perfect but better than to use the median (Michczyński 2007), which does not consider the probability variability within this calibration range (Telford et al. 2004). The mode (and the median) does allow for a unique value per date that is needed for the ANOVA.

\section{Charcoal botanical identification and analysis}

Extracted charcoal fragments were observed under an incident light microscope $(\times 200, \times 500, \times 1000)$ to identify the woody taxa that burned. Identifications were realized with the help of specialist reference wood anatomy books (e.g., Jacquiot 1955; Jacquiot et al. 1973; Schweingruber 1990), and some specific studies on wood charcoal anatomy notably for Larix and Picea, for Betula, and for Empetraceae/ Ericaceae. Because Larix and Picea can only be distinguished from each other in exceptional cases, they have been gathered under the taxon "type Larix-Picea" (Talon 1997). Betula trees can be distinguished from Betula shrubs (Hellberg and Carcaillet 2003). With regard to Ericaceae and Empetraceae, genera or species have been identified when possible based on the anatomy of the medulla: Arctostaphylos, Empetrum, Erica, Rhododendron, Vaccinium myrtillus, V. vitis-idaea, $V$. uliginosum (Talon 2004). Further, Pinus sylvestris (a mountain tree, growing up to $2000 \mathrm{~m}$ ) and $P$. uncinata (a true subalpine tree growing from 1500 to $2500 \mathrm{~m}$ asl) cannot be distinguished based on their wood anatomy, and are thus labeled $P$. sylvestris/uncinata. The assemblages of charcoal are considered to correspond mainly to dead woody debris, especially that lying on the ground, and to living twigs of trees and shrubs which can easily burn due to their small diameters or their low height in the vegetation (Bégin and Marguerie 2002; Kasin et al. 2017).

Charcoal was weighed and expressed in terms of charcoal mass (= anthracomass) relative to the dry soil mass ( $\mathrm{mg}_{\mathrm{CHAR}} \cdot \mathrm{kg}_{\text {soil }}{ }^{-1}$ or ppm; see Carcaillet and Talon 2001). The charcoal mass was calculated per profile and per layer. The representation of past burned biomass based on anthracomass presents distortion potential due to the different consumption of species (Fréjaville et al. 2013a), burning conditions (Asgough et al. 2011), and the assumed resistance of charcoal to weathering processes in soil 
depending on soil type, burning conditions, and plant anatomy (Preston and Schmidt 2006). However, the representation of assemblages based on charcoal mass still remains an efficient way to figure out what the plant biomass had been at the time of the burning events.

Charcoal assemblages were expressed as a percentage of the identified charcoal mass per taxon and per layer; unidentified charcoal fragments were not considered in this calculation. Unidentified charcoals were those fragments with too few anatomical features for definitive identification, or glassy charcoals whose provenances still remain unknown despite experimentations (Théry-Parizot 2002). Taxa assemblages per layer were used for Correspondence Analysis (CA) to statistically distinguish the main organization of burned woody assemblages, and notably to test whether assemblages are distributed according to sites and to elevation. CA were computed using FactoMineR of the $R$ package (Lê et al. 2008). For synthetic representation, charcoal concentrations per layers were averaged per taxon and per profile to calculate the composition gradient along the elevation. This averaging was possible because each charcoal layer is not stratified due to soil bioturbation (Carcaillet 2001). The layers from a given profile were thus considered as replicates for that profile. For that purpose, infrequent or poorly abundant taxa were clustered, as in "broadleaved trees" for Acer, Alnus cf. incana, Betula, Corylus, Fraxinus, cf. Populus; "Ericaceae" for Arctostaphylos, Erica, Rhododendron, Vaccinium; "other shrub" for Alnus cf. viridis, Berberis, Juniperus, cf. Ononis, Rhamnus, Rosa, Rosaceae Maloideae, and cf. Salix, Clematis alpina, the only liana found, was included with "other shrubs" because it generally spread in the shrub layer. The full list of taxa identified per profile and per layer is in the supplementary information (Table S2).

\section{Results}

\section{Fire history}

The three chronologies of burning present some differences of pattern at century scale (Fig. 1), but all three sites show a common multimillennial motif. The main fact of note is that no dating covers the period before 7700 cal BP. At Lanslevillard, the first occurred at about 7200 cal BP, while the first at Aussois occurred at 6500 cal BP. Most datings of soil charcoal coincide with a vague mid-Holocene period, with important evidences of biomass burning from 6500 to 2700 cal BP, although at Lanslevillard this period is much less pronounced. It is mostly well figured and continuous at St Michel and at Aussois. The third period, from 2800 to the present, is characterized by repetition of rather brief episodes of burning intermingled with episodes without burning. These brief episodes concern two sites out of three together, notably at $2400-2100$ cal BP (three sites) and 1700-1400 cal BP (three sites). From 1200 to the present the common pattern is less obvious, although biomass burned simultaneously at Lanslevillard and Aussois firstly between 1000 and 700 cal BP and secondly between 500 and 300 cal BP. Finally, the sites of St Michel and Aussois present a common burning phase during the last 300 years.

When observing the mid-Holocene, from 6500 to $2700 \mathrm{cal}$ BP, it appears that soil charcoal dates occurred both in lower and higher altitudes at all sites (Fig. 1). From 4000 to 2000 cal BP, the number of dates decreases in the upper altitudes, earlier in St Michel, later in Lanslevillard. From 2000 cal BP, no dates on 
soil charcoal have been obtained above $1900 \mathrm{~m}$ in Aussois, $1950 \mathrm{~m}$ in St Michel, and $2050 \mathrm{~m}$ in Lanslevillard. The occurrence of fire thus depends on both time and altitude.

The violin-plots of radiocarbon datings provide evidence that the distribution of biomass burning in St Michel is significantly different from those of Aussois and Lanslevillard (Fig. 2; ANOVA and Tukey-test: $F$ $=7.279 ; p<0.01$, Fig. 2). Further, the violin-plot of St Michel is rather regular, although a gentle bulge around 6000 cal BP illustrates a first but minor phase of burning before the main bulge that is centred around 4200 cal BP. At Lanslevillard, the main bulge is around 2200 cal BP, but a minor one occurs around 5500 cal BP. Only Aussois shows a clear bimodal biomass burning chronology with a first phase peaking around $4000 \mathrm{cal}$ BP, and a second around $800 \mathrm{cal}$ BP. These patterns demonstrate a certain independence in fire histories between sites. Both sites situated on south-facing slopes present two different chronologies, and both sites situated in very different environments (north- versus south-facing slopes, soil quality) are not significantly different (ANOVA, $p=0.71$ ).

\section{Past burned biomass per site and per altitude}

CA based on the percentage of taxa per layer shows that each site can be distinguished easily (Fig. 3a). Axis- 1 captures $25.4 \%$ of the variance of the CA, and $17.1 \%$ by axis- 2 , totalizing $42.5 \%$ on this first factorial map. The barycenter of Lanslevillard assemblages is on the positive side of both axes, and at the opposite is situated the Aussois barycenter (Fig. 3a). Axis-1 distinguishes well all Lanslevillard assemblages from the others, with assemblages above $2000 \mathrm{~m}$ asl situated on the negative part of axis2. Interestingly, all assemblages $>2000 \mathrm{~m}$ asl of the three sites are concentrated on the negative part of axis-2, except one from Aussois. St Michel assemblages from altitudes below $2000 \mathrm{~m}$ are intermediate and much more dispersed than those of Aussois and Lanslevillard for the same altitude class, indicating a greater heterogeneity and diversity of plant assemblages in the lower subalpine belt. Axis- 1 opposes Pinus cembra and Larix-Picea on the positive side and Pinus sylvestris-uncinata on the negative side. Axis-2 is characterized by Abies on the negative side (Fig. 3a). Alnus incana (axis-1), V. cf. vitis-idaea, and V. cf. uliginosum (axis-2) are indicated because there are strong correlations with these axes (Fig. 3a), but their actual contributions to the axes are lower than the average.

These statistical outputs of the CA are well illustrated in figure 3c, which depicts the structure of assemblages (in percentage of anthracomass) along the altitudinal gradient per site. The past subalpine vegetation at St Michel was broadly dominated by Pinus cembra, except below $1800 \mathrm{~m}$ where $P$. sylvestris/uncinata dominated burned biomass. The other taxa are minor components of the burned vegetation, i.e., Acer (three taxa), Alnus (two taxa), Abies, type Larix-Picea, Betula, Ericaceae (five taxa), Juniperus, Rosaceae (Prunus, Malloideae, Rosa), Corylus, Fraxinus, cf. Populus, cf. Salix, Sambucus (Table SI-2). At Aussois, charcoal of P. sylvestris/uncinata is dominant from 1700 to $2100 \mathrm{~m}$, whereas Pinus cembra abound above that altitude. The occurrence of Ericaceae is important, i.e., four taxa chiefly Arctostaphylos and Erica. Other taxa are Abies, type Larix-Picea, Acer, Betula, Berberis, Juniperus, cf. Ononis, Prunus, Rhamnus, cf. Salix (Table S2). At Lanslevillard, the lowest altitudes are characterized by both Abies and type Larix-Picea, whereas the upper altitudes are dominated by $P$. cembra. The minor component of the burned biomass is composed of P. sylvestris/uncinata, Alnus, Betula, Clematis, 
Ericaceae (six taxa), cf. Salix, Sambucus (Table S2). These three graphs clearly show that the burned biomass differs between sites in the lower subalpine belt, but the compositions converge and are homogeneous in the upper subalpine belt (Fig. 3c).

Charcoal concentrations per soil profile (ppm) show a general decrease along the altitudinal gradient (Fig. 3b), but there are some differences between sites. If the decrease is significant for St Michel following negative exponential $(r=0.96, p<0.001)$, it is not significant for Aussois or Lanslevillard and much more stochastic. At Lanslevillard, charcoal concentrations are homogeneous along the gradient. Considering all data, the altitudes of 2050-2100 $\mathrm{m}$ asl appear as a threshold in the charcoal concentrations, which drop below 120 ppm between 2100 and 2500 m (higher subalpine belt). The mean soil charcoal concentrations are not significantly different between sites (ANOVA, Tukey HSD post-hoc test; $F=2.901 ; p=0.077): p=0.167$ for St Michel (mean $\pm S E, 39 \pm 17 \mathrm{ppm})$ versus Aussois $(140 \pm 60$ $\mathrm{ppm}), p=0.107$ for St Michel versus Lanslevillard (163 $\pm 37 \mathrm{ppm})$, and $p=0.923$ for Aussois versus Lanslevillard.

\section{Discussion}

The present study shows that biomass burning, a surrogate fire regime reconstruction based on soil charcoal dating, presents both similitudes and subtle differences between subalpine sites at millennial scale despite obvious contrasts in the local conditions of fire spread. Indeed, a site characterized by conditions of climatic, edaphic, and topographic dryness, with burned biomass dominated by fire-prone trees (Aussois), has a non-significant pattern than a wetter and colder site with poorly flammable species (Lanslevillard; Fig. 2). Surprisingly contrasting to one working hypothesis, these two sites did not reveal clear differences of burning periods (Fig. 1 and 2), while the burned biomass was significantly different (Fig. 3). The reconstruction of burned biomass was a crucial condition of the present study to test whether fuel composition might have contributed to determine some similitudes or differences of biomass burning between sites. Finally, Aussois was actually dominated - as it is at present - by fireprone vegetation with some species possessing fire-resistance traits (notably the three pine species $P$. sylvestris, $P$. uncinata, and $P$. cembra), while burned biomass at Lanslevillard was characterized by poorly flammable species/community (Larix, Picea, Abies) with low fire-resistance traits (Picea, Abies) (Fréjaville et al., 2013b, 2018b; Bär and Mayer, 2020). Finally, the most significant differences concern: (i) the two sites exposed to the south (Aussois and St Michel), both in terms of burning chronology (Fig. 1 and 2) and burned biomass (Fig. 3); and (ii) the fact that on north-facing slopes the burning chronology seems episodic, whereas chronologies were more continuous on south-facing slopes whatever the dating number (Fig. 1). The following discussion develops over four paragraphs, namely: (i) the nesting of processes highlighted by the present study; (ii) the evidence of land use during the late Holocene; and, finally, (iii) the question of the absence of burning evidences during the early Holocene that cannot be the evidence of the absence of fire. 


\section{Nesting broad and local patterns of subalpine biomass burning history}

If a multi-millennial pattern can be discerned at the valley scale, suggesting a control of biomass burning by the regional climate (three main similar periods at the three sites, no clear differences in burning between the two most contrasting sites), at times local drivers can offset this common pattern, notably by promoting fire when other sites seem little or not all affected (i.e., around 7500-7000 at St Michel) or by suppressing fires (i.e., since 2000 years ago in St Michel) while other sites still remain active. This suggests nesting processes in the control of fire regimes in the subalpine forest ecosystem, involving large-scale and local drivers. Interestingly, the effect of north- versus south-facing slopes was highlighted at millennial scale based on sedimentary lacustrine charcoal from the same region of the western Alps (Leys and Carcaillet 2016), showing that fire frequency was more homogeneous between sites on northfacing slopes than on south-facing slopes where it was more stochastic, perhaps due to natural drivers but chiefly down to the effect of human activities. However, the main finding of the present study is that a drier site with more fire-prone vegetation does not necessarily produce a longer or more continuous chronology. However, the colder, wetter site depicts a more episodic chronology, suggesting that it has been less frequently susceptible to fire spread, which is also an output of one model-based study set out by Schumacher and Bugmann (2006).

Many have underscored the importance of human social processes as probable explanations of the alteration of fire regimes in high mountain since 4000 or 4500 years ago (depending on the study, e.g., Leys and Carcaillet 2016; Vannière et al. 2016). The main period of biomass burning in the subalpine belt or high altitudes in the Alps, whatever the analytical methods used (sedimentary charcoal versus soil charcoal), is the mid-Holocene from ca 6000 to 2500 cal BP, although the limits of this 'mid-Holocene' period vary between studies due to the number of observations, the numerical methods implemented, and site locations (Leys and Carcaillet 2016; Vannière et al. 2016; present outputs). To avoid speaking about a 'period' with vague limits, it is preferable to evoke a humped-back pattern of biomass burning, peaking somewhere between 6000 and 2500 cal BP depending on local drivers, including the social. As classically evoked with paleo-data, it is not easy to determine what, between frequency, severity, or extent, explains the changes in biomass burning history. Several studies mentioned the decrease in available biomass to explain the changes, while frequency was little involved as driver but rather as a consequence of this change in forest biomass (Blarquez et al. 2012; Vannière et al. 2016). One study in the same valley as the present study evidenced a sharp increase in fire frequency about 7500-7000, pre-dating and explaining the drop in biomass and the change in plant composition (Genries et al. 2009a). Similar results were obtained between 2500 and 1800 cal BP in other sites with final total woodland suppression after the rise in fire frequency, while from 7000 to 2500 cal BP the fire frequency and the vegetation were very steady (Genries et al. 2009c), contrasting with the frequently reported humped-back mid-Holocene biomass burning in the western subalpine ecosystems (Leys and Carcaillet 2016). Further south (ca 50-80 km) in the driest and warmer area of the western Alps, similar chronologies of biomass burning, based on 29 and 54 datings of soil charcoal respectively (Talon 2010; Saulnier et al. 2015), show long periods of 
burning starting around 7000 or 9000 cal BP, respectively, and lasting until ca 250 cal BP. Most of these charcoals came from north-, west-, or east-facing slopes. However, the best we can say is that the maximum of biomass burning occurred from 5000 to 500 cal BP (this will remain so, at least until a statistical analysis is conducted to accurately indicate the strength and the limits of these chronologies). An interesting fact of these studies is that most of the dated soil charcoal sampled in the higher subalpine belt (2200-2900 m asl) is concentrated during this 5000-500 cal BP period (Talon 2010; Saulnier et al. 2015), contrary to the present study where the upper subalpine belt (2100-2500 m) burned earlier, between 6500 and 3000 cal BP, mostly on south-facing slopes (Fig. 1). This highlights regional/local differences. However, based on sedimentary charcoal, the fire frequency in the subalpine belt in the southern Alps attained a maximum (humped-back) about 4000-3700 cal BP, during a long period that started $7000 \mathrm{cal} \mathrm{BP}$ and ended at ca $3000 \mathrm{cal}$ BP (Carcaillet and Blarquez 2017), matching with the present chronology (Fig. 1).

\section{The obvious role of land use}

A general fire motif of all these reported studies is that with time the biomass burning generally starts to decrease sometime between 4000 and $2000 \mathrm{cal}$ BP until today in the western Alps, according to sites/valleys/massifs (e.g., Vannière et al. 2016). In the northwestern Alps (Fig. 1), the evidence of fire in the upper subalpine became more and more rare after 3000 cal BP, probably prefiguring the current subalpine grassland. Further, the brief episodes of biomass burning - common to two or three sites during the last 2500 years (Fig. 1) - could well be related to a phase of land use expansion using fire to clear forest understoreys or to create grasslands, although brief climatic episodes favorable to natural fire occurrence (i.e., warmer, drier periods) cannot be ruled out. The reporting of such motifs with the same dates in other areas of the western Alps would be needed to support a general climate interpretation. Similarly, the absence of quantitative archaeological data in the study area hinders any possibility of reaching firm conclusions as to the social effect on the sequential motif of brief episodes in the last 2500 years.

In southern sites, this link between charcoal dates and altitude is less obvious because many datings have been obtained covering the last 3000 years (Talon 2010) or after 4500 cal BP (Saulnier et al. 2005), suggesting differences between sites/valley/massif. Associated to the altitudinal gradient is the charcoal concentration per soil profile that shows a general decrease along the altitudinal gradient in response to increasing stress, although this pattern varies a lot between sites (Fig. 3b). These distributions were expected (Carcaillet and Talon 2001) and correspond to a common subalpine pattern (Carnelli et al. 2004; Talon 2010) well explained by the primary productivity that decrease with the elevation, and the assumed low resilience rate of woodlands to disturbances near the treeline.

\section{The early Holocene: No fire or bias due to residence time of soil charcoal?}

On a first approach, the early Holocene seems characterized by the absence of biomass burning, but this fact needs a careful and thorough interpretation, because the absence of evidence is not the evidence of 
absence. If we compare the chronology of St Michel with a charcoal sedimentary series available at the same place (Genries et al. 2009a), sampled from a pond at $150 \mathrm{~m}$ from the present three plots situated at $1950 \mathrm{~m}$, the sediments demonstrate an abundance of charcoal from 9000 to $7000 \mathrm{cal}$ BP, while soil reveals no charcoal. After 7000 cal BP, the sedimentary charcoal concentrations decrease, while soil charcoal starts to sequestrate (Fig. 1). Such similar differences between charcoal stocks in sediments and in soil have been previously reported (e.g., Ohlson et al. 2013; Couillard et al. 2019). Such differences suggest that the residence time of macro-charcoal might be limited due to the fragmentation of charred particles under the effect of freeze-thaw, roots, and soil invertebrates (Carcaillet 2001), or to the biochemical decay of charcoal which depends on their chemical stability (Preston and Schmidt 2006; Ascough et al. 2011). Polyaromatic charcoals are the most stable and resistant to weathering or decay. Leaching or degradation of hydrophobic compounds of soil charcoal would decrease their residence time (Criscuoli et al. 2014). Polyaromatics are produced at higher temperatures (e.g., Novakov et al. 1997; Alexis et al. 2010), i.e., during very intense fires. Such intense fires - suitable for producing polyaromatics - do not seem to be a common feature in subalpine forests (Genries et al. 2009b); further, the extreme conditions needed to obtain intense fires are not so common (Dupiré et al. 2017; Fréjaville et al. 2018a) and then, simply, subalpine fires are rare at present.

Consequently, there are two alternatives hypotheses: either the stock of charcoal $>0.4 \mathrm{~mm}$ was too fragmented and weathered in the soil resulting in a rather brief residence time and thus its disappearance, or fire intensities changed during the Holocene around $7000 \mathrm{cal}$ BP from low to highly intense. The change would have resulted in the disappearance of poorly aromatic charcoal of the early Holocene and the sequestration of highly polyaromatic charcoal stock produced by intense fires from 7000 cal BP to the present. This hypothesis still remains open and could be tested with FTIR spectra analyses on sedimentary charcoal (e.g., Maezumi et al. 2021).

\section{Conclusion}

Our working hypothesis assuming that the strength of mountain natural and local drivers should offset the effects of regional climate is not validated. The homogeneity of the fire regime between sites thus underscore that climate was the main historical driver during the Holocene. Long-term subalpine fires are obviously controlled by climate at millennial scale. Local conditions count for little in determining variability the millennial to century scale. As already depicted in several studies, the mid-Holocene was a chief period for climatic biomass burning in the subalpine zone of the western Alps, while fires since about 2500 years ago appear much more episodic, prompting the assumption that human society has exercised a key role on their control.

\section{Declarations}

\section{Ethics approval and consent to participate}

Not applicable 


\section{Consent for publication}

Not applicable

\section{Availability of data and material}

All data generated or analysed during this study are included in this published article and its supplementary information files.

\section{Competing interests}

The authors declare that they have no competing interests

\section{Funding}

Financial support was provided to C.C. through a French incentive action fund from the Institut National des Sciences de l'Univers (INSU ACI ECCO) and by an ARTEMIS grant for datings (PALEOFIRE program; INSU-CNRS, France).

\section{Authors' contributions}

C.C. conceived and designed the study; C.C. realized all the samplings, and most of the charcoal identification; B.B. analyzed the radiocarbon dating, and F.C. contributed to statistical analyses; C.C. interpreted the results and wrote the manuscript, which was commented on and improved by B.B. and F.C.

\section{Acknowledgements}

We thank Marion Martinez, who assisted with charcoal identification on the Lanslevillard site during her Master internship at the EPHE, and also Adam Ali, Olivier Blarquez, Jean-Jacques Brun, Lydie Feltgen, Brice Mourier, Brigitte Talon, and Michel Thinon for their help during fieldwork. This study could hardly have been carried out without the availability of the charcoal lab facilities at the IMBE, Marseille, notably during the internship of Marion Martinez; many thanks to Brigitte Talon for her kind hospitality. The English text was edited by SEES-Editing Ltd.

\section{Authors' details}

(1) Paris Sciences \& Lettres University (PSL), École Pratique des Hautes Études (EPHE), F-75014 Paris, France

(2) Univ Lyon, Université Claude Bernard Lyon 1, CNRS, ENTPE (UMR 5023 LEHNA), F-69622 Villeurbanne, France

(3) NaturCom Chair, Université de Montpellier, F-34000 Montpellier, France

(4) MARBEC (Université de Montpellier, CNRS, Ifremer, IRD), F-34000 Montpellier, France 


\section{References}

1. Alexis MA, Rumpel C, Knicker H, Leifeld J, Rasse D, Péchot N, Bardoux G, Mariotti A (2010) Thermal alteration of organic matter during a shrubland fire: a field study. Org Geochem 41:690-697.

2. Allen TFH (2009) Hierarchy theory in ecology. In: Jorgensen SE (ed) Ecosystem ecology - a derivative of encyclopedia of ecology. Elsevier, Amsterdam.

3. Ascough PL, Bird MI, Francis SM, Thornton B, Midwood AJ, Scott AC, et al (2011) Variability in oxidative degradation of charcoal: influence of production conditions and environmental exposure. Geochim Cosmochim Acta 75:2361-2378.

4. Bär A, Mayr S (2020) bark insulation: ten central alpine tree species compared. For Ecol Manag 474:118361. doi 10.1016/j.foreco.2020.118361

5. Bartoli C (1966) Etudes écologiques sur les associations végétales forestières de la Haute Maurienne. Ann For Sci 23 :432-751.

6. Bégin $Y$, Marguerie $D$ (2002) Characterization of tree macroremains production in a recently burned conifer forest in northern Québec, Canada. Plant Ecol 159:143-152.

7. Blarquez O, Carcaillet C, Elzein TM, Roiron P (2012) Needle accumulation rate model-based reconstruction of palaeo-tree biomass in the western subalpine Alps. Holocene 22:579-587 DOI: $10.1177 / 0959683611427333$

8. Bond WJ, Keeley JE (2005) Fire as a global "herbivore": the ecology and evolution of flammable ecosystems. Trends Ecol Evol 20:387-394. http://dx.doi.org/ 10.1016/j.tree.2005.04.025.

9. Carcaillet C (1998) A spatially precise study of fires, climate and human impact within the Maurienne valley, North French Alps. J Eco/86:384-396. doi 10.1046/j.1365-2745.1998.00267.x

10. Carcaillet C (2001) Soil particles reworking evidences by AMS ${ }^{14} \mathrm{C}$ dating of charcoal. C R Acad Sci Paris, Série Earth Plant Sci 332:21-28. doi http://doi.org/10.1016/S1251-8050(00)01485-3

11. Carcaillet C, Ali AA, Blarquez O, Genries A, Mourier B, Bremond L (2009) Spatial variability of fire history in subalpine forests: from natural to cultural regimes. Ecoscience 16:1-12. doi 10.2980/16-13189

12. Carcaillet C, Blarquez $O$ (2017) Fire ecology of a tree glacial refugium on a nunatak with a view on Alpine glaciers. New Phyto/216, 1281-1290. https://doi.org/10.1111/nph.14721

13. Carcaillet C, Talon B (2001) Soil carbon sequestration by Holocene fires inferred from soil charcoal in the dry French Alps. Arct Antarc Alp Res 33:282-

288. http://doi.org/10.1080/15230430.2001.12003432

14. Carcaillet C, Thinon M (1996) Pedoanthracological contribution to the evolution of the upper treeline in the Maurienne Valley (North French Alps): Methodology and preliminary data. Rev Palaeobot Palyno/ 91:399-416 https://doi.org/10.1016/0034-6667(95)00060-7

15. Carnelli AL, Theurillat JP, Thinon M, Vadi G, Talon B (2004) Past uppermost tree limit in the central European Alps (Switzerland) based on soil and soil charcoal. Holocene 14:393-405. 
16. Clark JS, Lynch J, Stocks B, Goldammer J (1998) Relationships between charcoal particles in air and sediments in west-central Siberia. Holocene 8:19-29.

17. Couillard PL, Tremblay J, Lavoie M, Payette S (2019) Comparative methods for reconstructing fire histories at the stand scale using charcoal records in peat and mineral soils. For Ecol Manag 433:376-385. https://doi.org/10.1016/j. foreco.2018.11.015.

18. Criscuoli I, Alberti G, Baronti S, Favilli F, Martinez C, Calzolari C, et al. (2014) Carbon Sequestration and Fertility after Centennial Time Scale Incorporation of Charcoal into Soil. PLoS ONE. https://doi.org/10.1371/journal.pone.0091114

19. Dupire S, Curt T, Bigot S (2017) Spatio-temporal trends in fire weather in the French Alps. Sci Total Environ 595:801-817. https://doi.org/10.1016/j.scitotenv.2017.04.027

20. Dupiré S, Curt T, Bigot S, Fréjaville T (2019) Vulnerability of forest ecosystems to fire in the French Alps. Eur J For Res 138:813-830. 10.1007/s10342-019-01206-1

21. Flannigan MD, Krawchuk MA, de Groot WJ, Wotton BM, Gowman LM (2009) Implications of changing climate for global wildland fire. Int $J$ Wildland Fire 18:483e507, https://doi.org/10.1071/WF08187.

22. Fréjaville T, Carcaillet C, Curt T (2013a) Calibration of charcoal production from trees biomass for soil charcoal analyses in subalpine ecosystems. Quat Intern 289:16-23 doi:

10.1016/j.quaint.2012.02.043

23. Fréjaville T, Curt T, Carcaillet C (2013b) Bark flammability as a fire-response trait for subalpine trees. Front Plant Sci. doi: 10.3389/fpls.2013.00466

24. Fréjaville T, Curt T, Carcaillet C (2018a) Higher potential fire intensity at the dry margins of European mountain trees. J Biogeogr 45:2003-2015 D0l:10.1111/jbi.13386

25. Fréjaville T, Vilà-Cabrera A, Curt T, Carcaillet C (2018b) Aridity and competition drive fire resistance trait covariation in mountain trees. Ecosphere. DOI: 10.1002/ecs2.2493

26. Gao X, Giorgi F (2008) Increased aridity in the Mediterranean region under greenhouse gas forcing estimated from high resolution simulations with a regional climate model. Glob Planet Change 62:195-209. https://doi.org/10.1016/j.gloplacha.2008.02.002

27. Gavin DG (2001) Estimation of inbuilt age in radiocarbon ages of soil charcoal for fire history studies. Radiocarbon 43:27-44.

28. Gavin DG, Brubaker LB, Lertzman KP (2003) Holocene fire history of a coastal temperate rain forest based on soil charcoal radiocarbon dates. Ecology 84:186-201.

29. Genries A, Mercier L, Lavoie M, Muller SD, Radakovitch O, Carcaillet C (2009a) The effect of fire frequency on local cembra pine populations. Ecology 90:476-486. Doi: 10.1890/07-1740.1

30. Genries A, Morin X, Chauchard S, Carcaillet C (2009b) The function of surface fires in the dynamics and structure of a formerly grazed old subalpine forest. $J$ Eco/ $97: 728-741$, doi: $10.1111 / \mathrm{j} .1365-$ 2745.2009.01518.x 
31. Genries A, Muller SD, Mercier L, Bircker L, Carcaillet C(2009c) Fires control spatial variability of subalpine vegetation dynamics during the Holocene in the Maurienne valley (French Alps). Ecoscience 16:13-22. https://doi.org/10.2980/16-1-3180

32. Geologic map 775 (Debelmas, J., 1989) Carte Géologique de la France, feuille de Modane Map 775, 1:50 000. Edition du BRGM, Orléans, France.

33. Geologic map 776 (Fudral, S., Deville, E., Nicoud, G., Pognante, U., Guillot, P.L., Jaillard, E., 1994) Carte Géologique de la France, feuille de Lanslebourg-Mont-d'Ambin Map 776, 1:50 000. Edition du BRGM, Orléans.

34. Hajdas I, Schlumpf N, Minikus-Stary N, Hagedorn F, Eckmeier E, Schoch W, Burga C, Bonani G, Schmidt MWI, Cherubini P (2007) Radiocarbon ages of soil charcoals from the southern Alps, Ticino, Switzerland. Nucl Instrum Methods Phys Res B 259:398-402

35. Hellberg E, Carcaillet C (2003) Wood anatomy of West-European Betula: quantitative descriptions and applications for routine identification in paleoecological studies. Ecoscience 10:370379. https://doi.org/10.1080/11956860.2003.11682786

36. Im ES, Coppola E, Giorgi F, Bi X (2010) Local effects of climate change over the Alpine region: A study with a high resolution regional climate model with a surrogate climate change scenario. Geophys Res Lett 37:L0570.

37. IPCC (2021) Climate Change 2021: The Physical Science Basis. Contribution of Working Group I to the Sixth Assessment Report of the Intergovernmental Panel on Climate Change. Cambridge University Press, Cambridge.

38. Jacquiot C (1955) Atlas d'anatomie des bois de conifères. Centre technique du bois, Paris.

39. Jacquiot C, Trenard Y, Dirol D (1973) Atlas d'anatomie des bois des Angiospermes (Essences feuillues). Centre technique du bois, Paris.

40. Kasin I, Ellingsen VM, Aspun J, Ohlson M (2017) Spatial and temporal dynamics of the soil charcoal pool in relation to fire history in a boreal forest landscape. Can J For Res 47:28-35.

41. Lê S, Josse J, Husson F (2008) FactoMineR: An R Package for Multivariate Analysis. J Stat Software 25:1-18.

42. Leys B, Carcaillet C (2016) Subalpine fires: the roles of vegetation, climate and, ultimately, land uses. Clim Change 135:683-697 https://doi.org/10.1007/s10584-016-1594-4

43. Lingua $E$, Cherubini $P$, Motta R, Nola $P$ (2008) Spatial structure along an altitudinal gradient in the Italian central Alps suggests competition and facilitation among coniferous species. $J$ Veg Sci 19:425-436.

44. Loehman RA, Reinhardt E, Riley KL (2014) Wildland fire emissions, carbon and climate: Seeing the forest and the trees - Across-scale assessment of wildfire and carbon dynamics in fire-prone, forested ecosystems. For Ecol Manage 317:9-19.

45. Lynch JA, Clark JS, Stocks BJ (2004) Charcoal production, dispersal, and deposition from the Fort Providence experimental fire: Interpreting fire regimes from charcoal records in boreal forests. Can J. For Res 34:1642-1656. 
46. Maezumi SY, Gosling WD, Kirschner J, Chevalier M, Cornelissen HL, Jeinecke T, McMichael CNH (2021) A modern analogue matching approach to characterize fire temperatures and plant species from charcoal. Palaeogeogr Palaeoclim Palaeoecol

578. http://doi.org/10.1016/j.palaeo.2021.110580

47. Michczyński A (2007) Is it possible to find a good point estimate of a calibrated radiocarbon date? Radiocarbon 49:393-401. doi:10.1017/S0033822200042326

48. Moritz MA, Batllori E, Bradstock RA, et al., (2014) Learning to coexist with wildfire. Nature 515:5866. http://dx.doi.org/10.1038/nature13946.

49. Moritz MA, Parisien MA, Batllori E, et al., (2012) Climate change and disruptions to global fire activity. Ecosphere 3. http://dx.doi.org/10.1890/ES11-00345.1.art49.

50. Motta R, Lingua E (2005) Human impact on size, age, and spatial structure in a mixed European larch and Swiss stone pine forest in the Western Italian Alps. Can J For Res 35:1809-1820.

51. Mourier B., Poulenard J, Chauvel C, Faivre P, Carcaillet C (2008) Distinguishing subalpine soil types using extractible Al and Fe fractions and REE geochemistry. Geoderma 145:107-120. doi:10.1016/j.geoderma.2008.03.001

52. Novakov T, Cachier H, Clark JS, Gaudichet A, Macko S, Masclet P (1997) Characterization of particulate products of biomass combustion. In: Clark JS, Cachier H, Goldammer JG, Stocks B (eds), Sediment Records of Biomass Burning and Global Change, pp. 117-143. Springer Verlag, Berlin https://doi.org/10.1007/978-3-642-59171-6_6

53. Ohlson M, Tryterud E (2000) Interpretation of the charcoal record in forest soils: Forest fires and their production and deposition of macroscopic charcoal. Holocene 10, 519-525.

54. O’Neill RV (1988) Hierarchy theory and global change. In: Rosswall T, Woodmansee RG, Risser PG (eds) Scales and global change, pp 29-45. Wiley, New York.

55. Payette S, Delwaide A, Schaffhauser A, Magnan G (2012) Calculating long-term fire frequency at the stand scale from charcoal data. Ecosphere. https://doi.org/ 10.1890/ES12-00026.1.

56. Payette S, Gagnon R (2005) Late Holocene deforestation and tree regeneration in the forest-tundra of Quebec. Nature 202:469-461.

57. Preston CM, Schmidt M.W.I., (2006). Black (pyrogenic) carbon: a synthesis of current knowledge and uncertainties with special consideration of boreal regions. Biogeosciences 3:397-420.

58. Saulnier M, Talon B, Edouard JL (2015) New pedoanthracological data for the long-term history of forest species at mid-high altitudes in the Queyras Valley (Inner Alps). Quat Int 366:15-24

59. Schumacher S, Bugmann H (2006) The relative importance of climatic effects, wildfires and management for future forest landscape dynamics in the Swiss Alps. Glob Change Biol 12, 1435e1450, DOI 10.1111/j.1365-2486.2006.01188.x.

60. Schweingruber FH (1990) Anatomie europäischer Hölzer. Paul Haupt, Bern

61. Stuiver M, Reimer PJ, Reimer RW (2021) CALIB 8.2 [WWW program] at http://calib.org 
62. Talon B (1997) Etude anatomique et comparative de charbons de bois de Larix decidua Mill. et de Picea abies (L.) Karst. CR Acad Sci Paris Life Science 320:581-588.

63. Talon B (2010) Reconstruction of Holocene high altitude vegetation cover in the French Southern Alps: evidence from soil charcoal. Holocene 20:34-44.

64. Talon B (2004) Wood anatomical criteria for identification of European Boreo-Alpine Ericaceae. International symposium of wood sciences, IAWA-IAWS, 24-29 October 2004, Montpellier, France.

65. Talon B, Payette S, Filion L, Delwaide A (2005) Reconstruction of the long-term fire history of an oldgrowth deciduous forest in southern Québec, Canada, from charred wood in mineral soils. Quat Res 64:36-43.

66. Tasser E, Tappeiner U (2002) Impact of land use changes on mountain vegetation. App Veg Sci 5:173-184.

67. Tasser E, Walde J, Tappeiner U, Teutsch A, Noggler W (2007) Land use changes and natural reforestation in the Eastern Central Alps. Agr Ecosyst Environ 118:115-129

68. Telford RJ, Heegaard E, Birks HJB (2004) The intercept is a poor estimate of a calibrated radiocarbon age. Holocene 14:296-298.

69. Théry-Parisot I (2002) Fuel management (bone and wood) during the Lower Aurignacian in the Pataud Rock Shelter (Lower Palaeolithic, Les Eyzies de Tayrac, Dordogne, France). Contribution of experimentation. J Archaeol Sci 29:1415-1421.

70. Tian YQ, Davies-Colley RJ, Gong P, Thorrold BW (2001). Estimating solar radiation on slopes of arbitrary aspect. Agr For Meteorol 109:67-74.

71. Yocom Kent LL, Fulé PZ, Brown PM, Cerano-Paredes J, Cornejo-Oviedo E, Cortés Montano C, Drury SA, Falk DA, Meunier J, Poulos HM, Skinner CN, Stephens SL, Villanueva-Dìaz J (2017) Climate drives fire synchrony but local factors control fire regime change in northern Mexico. Ecosphere 8. Doi: 10.1002/ecs2.1709

72. Zumbrunnen T, Bugmann H, Conedera M, Bürgi M (2009) Linking forest fire regimes and climate - a historical analysis in a dry inner Alpine valley. Ecosystems 12:73-86. https://doi.org/10.1007/s10021-008-9207-3

\section{Tables}

Table 1. Main landscape features of sampling sites and number of radiocarbon datings per sites. 


\begin{tabular}{|c|c|c|c|}
\hline Site name & $\begin{array}{l}\text { Saint- } \\
\text { Michel }\end{array}$ & Aussois & Lanslebourg \\
\hline $\begin{array}{l}\text { Sampling } \\
\text { altitude } \\
\text { range }\end{array}$ & $\begin{array}{l}1700-2450 \\
\mathrm{~m} \text { asl }\end{array}$ & $1750-2380 \mathrm{~m}$ asl & $1965-2225 \mathrm{~m}$ asl \\
\hline $\begin{array}{l}\text { Longitude } \\
\left({ }^{\circ}\right)\end{array}$ & $45.24^{\circ} \mathrm{N}$ & $45.24^{\circ} \mathrm{N}$ & $45.28^{\circ} \mathrm{N}$ \\
\hline $\begin{array}{l}\text { Latitude } \\
\left({ }^{\circ}\right)\end{array}$ & $6.48^{\circ} \mathrm{E}$ & $6.75^{\circ} \mathrm{E}$ & $6.95^{\circ} \mathrm{E}$ \\
\hline $\begin{array}{l}\text { Slope } \\
\text { exposure }\end{array}$ & south & south & north \\
\hline $\begin{array}{l}\text { Slope } \\
\text { degree }\end{array}$ & $20-30^{\circ}$ & $20-30^{\circ}$ & $20-30^{\circ}$ \\
\hline Bedrock & $\begin{array}{l}\text { Westphalian } \\
\text { black (coal) } \\
\text { sandstones } \\
\text { and shales } \\
\text { Glacial } \\
\text { deposits }\end{array}$ & $\begin{array}{l}\text { Triassic dolomite, cargneule } \\
\text { and gypsum } \\
\text { Glacial deposits }\end{array}$ & $\begin{array}{l}\text { Cretacean marbles and } \\
\text { calcareous shales } \\
\text { Glacial deposits }\end{array}$ \\
\hline Soil & $\begin{array}{l}\text { Acidic } \\
\text { brown soil } \\
\text { pH 4.0-5.0 } \\
\end{array}$ & $\begin{array}{l}\text { Neutral brown soil } \\
\text { pH 5.5-6.5 }\end{array}$ & $\begin{array}{l}\text { Alkaline calcimorph } \\
\mathrm{pH}>7.0\end{array}$ \\
\hline $\begin{array}{l}\text { Climate } \\
\text { (mean } \\
\text { 土sd) } \\
\text { Alt. } \\
\text { weather } \\
\text { station } \\
\text { Period } \\
\mathrm{T}_{\text {Ann }} \\
\mathrm{T}_{\text {JJA }} \\
\mathrm{T}_{\text {DJF }} \\
\mathrm{P}_{\text {Ann }} \\
\mathrm{P}_{\text {JJA }}\end{array}$ & $\begin{array}{l}1360 \mathrm{~m} \text { asl } \\
{[1967--} \\
1999] \\
7.1 \pm 0.6{ }^{\circ} \mathrm{C} \\
14.4 \pm 0.9 \\
{ }^{\circ} \mathrm{C} \\
0.4 \pm 1.5{ }^{\circ} \mathrm{C} \\
947 \pm 184 \\
\text { mm.year }{ }^{-1} \\
204 \pm 59 \\
\mathrm{~mm}\end{array}$ & $\begin{array}{l}1490 \mathrm{~m} \text { asl } \\
{[1950-1999]} \\
7.2 \pm 0.6{ }^{\circ} \mathrm{C} \\
14.5 \pm 0.7{ }^{\circ} \mathrm{C} \\
0.7 \pm 1 .{ }^{\circ} \mathrm{C} \\
712 \pm 149 \mathrm{~mm} . \text { year }^{-1} \\
156 \pm 49 \mathrm{~mm}\end{array}$ & $\begin{array}{l}2000 \mathrm{~m} \text { asl } \\
{[1970-1999]} \\
2.5 \pm 1.0{ }^{\circ} \mathrm{C} \\
10.1 \pm 1.5^{\circ} \mathrm{C} \\
-4.2 \pm 1.8^{\circ} \mathrm{C} \\
925 \pm 233 \mathrm{~mm} . \text { year }^{-1} \\
247 \pm 96 \mathrm{~mm}\end{array}$ \\
\hline $\begin{array}{l}\text { Slope } \\
\text { exposure }\end{array}$ & South & South & North \\
\hline $\begin{array}{l}\text { Present- } \\
\text { day } \\
\text { vegetation }\end{array}$ & $\begin{array}{l}\text { Multi- } \\
\text { secular } \\
\text { subalpine } \\
\text { grasslands }\end{array}$ & $\begin{array}{l}\text { Multi-secular subalpine } \\
\text { grasslands intermixed with } \\
\text { mixed conifer forest (Pinus } \\
\text { cembra, Pinus uncinata, Picea } \\
\text { abies, Pinus sylvestris) }\end{array}$ & $\begin{array}{l}\text { Multi-secular subalpine } \\
\text { grasslands (upper altitudes) or } \\
\text { mixed conifer forest (Pinus } \\
\text { cembra, Pinus uncinata, Picea } \\
\text { abies, Larix decidua, Abies alba) }\end{array}$ \\
\hline $\begin{array}{l}{ }^{14} \mathrm{C} \\
\text { Dating } \\
\text { number }\end{array}$ & 43 & 26 & 24 \\
\hline
\end{tabular}

$\mathrm{T}_{\text {Ann: }}$ : mean annual temperature; $\mathrm{T}_{\mathrm{JJA}}$ : mean monthly temperature of June, July and August (summer); $\mathrm{T}_{\mathrm{DJF}}$ : mean monthly temperature of December, January and February (winter); $\mathrm{P}_{\mathrm{Ann}}$ : mean annual precipitation; $\mathrm{P}_{\mathrm{JJA}}$ : mean summer precipitation.

\section{Supplementary Table}

Table SI-1 is not available with this version. 
Figures

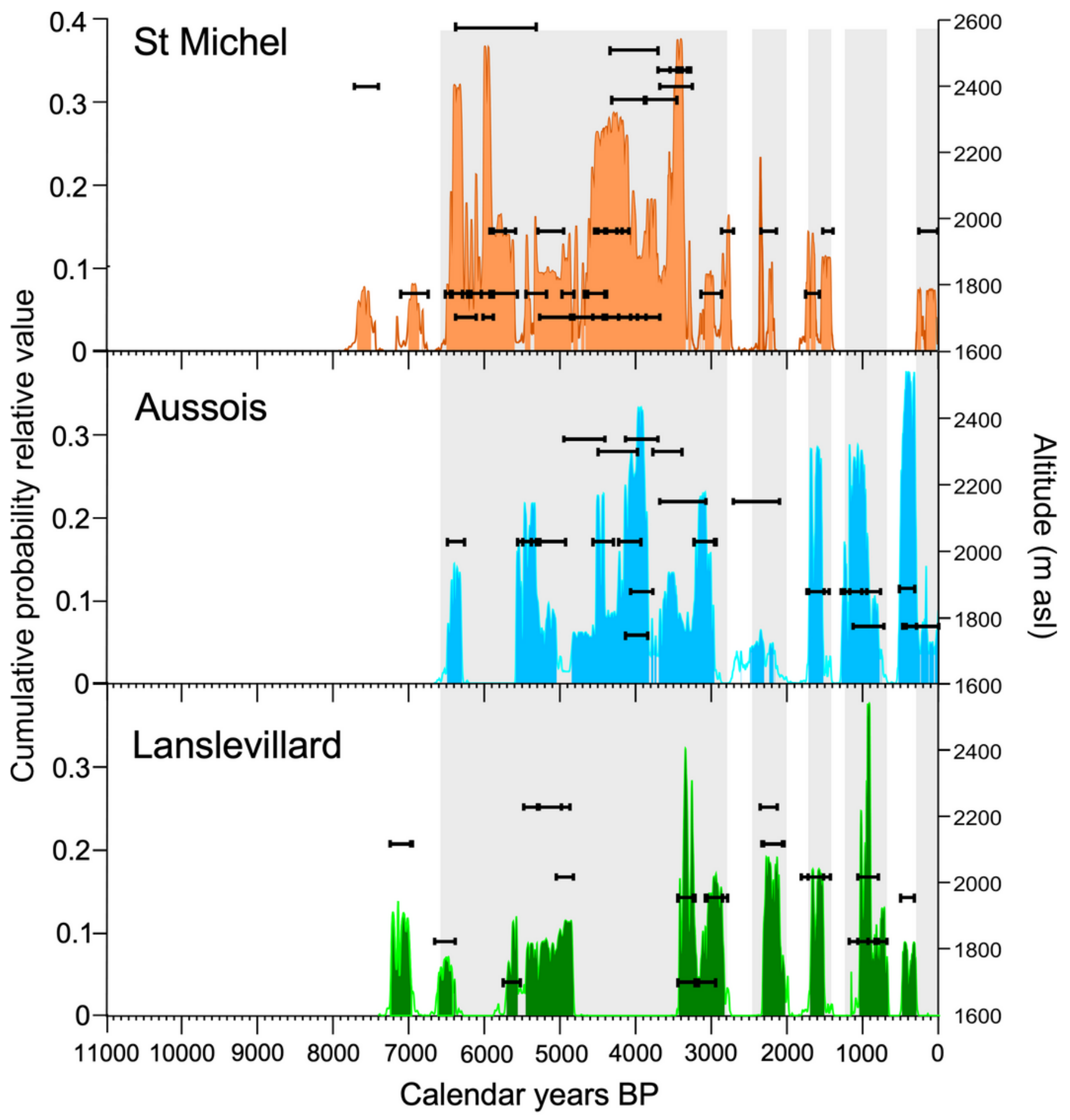

Figure 1

Biomass burning chronology during the Holocene, expressed in probability density function of calendar 14C dating: 43 dates at St Michel, 26 at Aussois, and 24 at Lanslevillard. ' 0 cal yr BP' corresponds to AD 1950 by convention. 


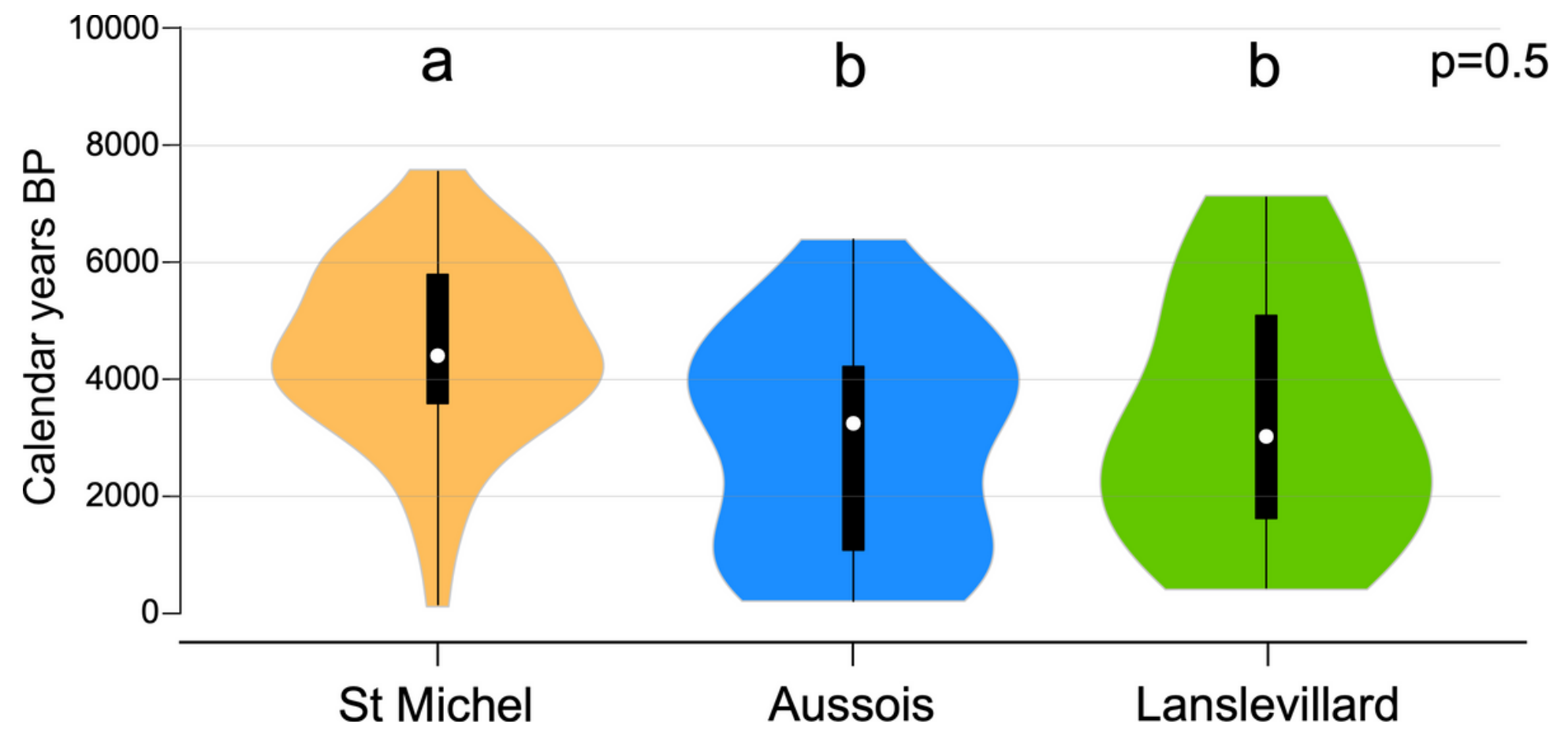

Figure 2

Violin-plots represent the distribution of datings per site. Yellow for St Michel, blue for Aussois, and green for Lanslevillard: the white dots represent the median and the black rectangles are the interquartile range, and the envelope is a kernel density estimation of the distribution. The different letters indicate significant differences at $p=0.05$ (ANOVA, Tukey HSD post-hoc test). 


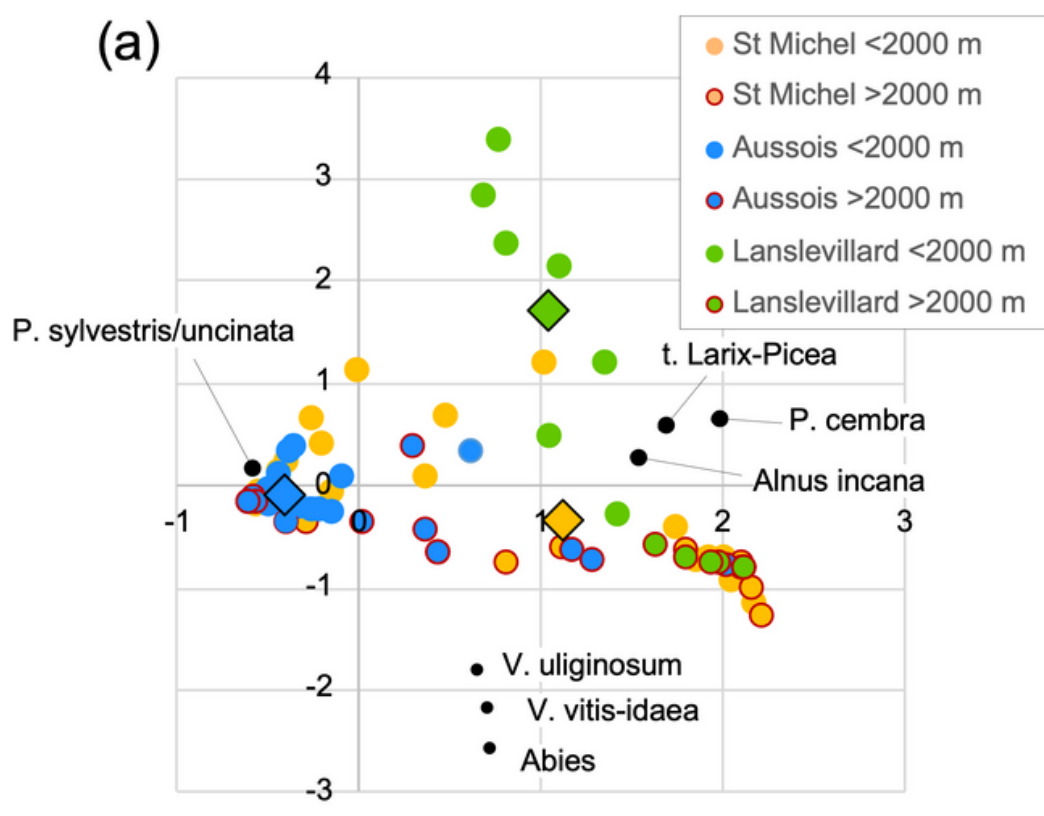

(c)

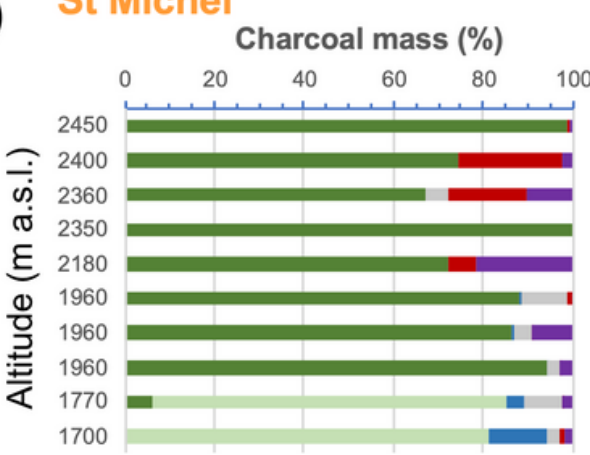

Aussois

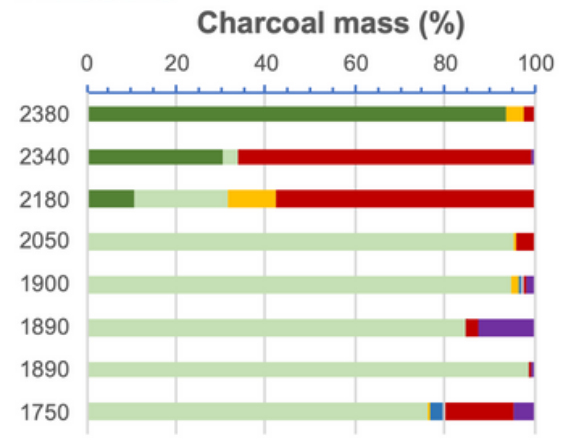

(b)

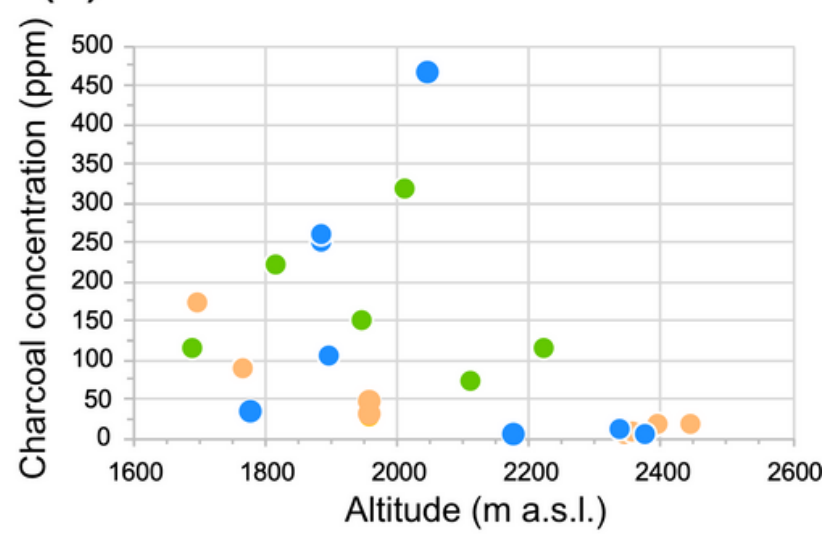

- Pinus cembra - type Larix/Picea nbroadleaved trees - other shrubs
Pinus sylvestris/uncinata - Abies alba

- Ericaceae

\section{Lanslevillard}

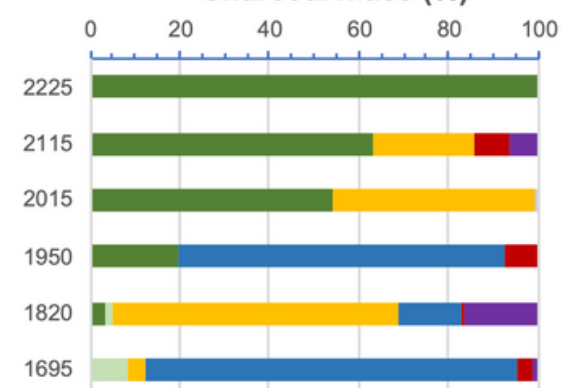

\section{Figure 3}

Synthesis of burned biomass at the three sites. (a) Biplot of axes 1 and 2 of a correspondence analysis based on identified charcoal assemblages per soil layer; dots correspond to layers, and large diamonds correspond to the barycenter of dots per site; dots with a red border are layers from plots $>2000 \mathrm{~m}$ asl. (b) Total charcoal concentration per profile (mgchar.kgsoil-1 or ppm) plotted against altitude. (c) Diagram of charcoal abundances plotted against altitude (percentage of soil charcoal mass per species averaged per profile); this representation depicts the structure of assemblages of burned biomass along the altitudinal gradient and per site. Common color chart in (a) and (b), such as yellow dots for St Michel, blue for Aussois, and green for Lanslevillard.

\section{Supplementary Files}

This is a list of supplementary files associated with this preprint. Click to download.

- CarcailletTabS2assemblages.xlsx 